\title{
TRIBUTE TO THE MEMORY OF JOHN LAWRENCE LECONTE.
}

By CHARles VAlentine Riley, WAshington, D. C.

Dr. John Lawrence LeConte died at his residence in Philadelphia, 5 Nov. I883. Nothing that we can say will render the memory of him more lasting or more dear, for he achieved preeminence in his chosen field of labor and won the love and respect of all who knew him.

LeConte was.born in New York, 13 May 1825 , and was graduated $M . D$. by the College of physicians and surgeons in 1846 . He moved to Philadelphia some years later, and after his marriage abandoned the practice of medicine. $\mathrm{He}$ was lieutenant-colonel and medical inspector in the United States army during the civil war and, from I 878 till the time of his death, chief clerk in the United States mint at Philadelphia.

Luckily for American natural science his fortune was such that, with these two exceptions, he held no positions, but was able to devote his time to entomology. His chosen specialty was the coleoptera, and in order to fully appreciate the magnitude of the work which he accomplished and the difficulties with which he had to contend, it is necessary to consider the state of entomology in this country as compared with Europe at the time he began to write, now almost forty years ago. Great activity at that time prevailed in Europe in all branches of entomology. In descriptive coleopterology Aubé, Erichson, Germar, Klug, Lacordaire, Mannerheim, Mulsant, Schönherr, Ser- ville, Solier, Stephens and others were active at that period. Others equally eminent had died shortly before and many came into prominence shortly afterward. Naturalists there were aided as well by the large number of skilled and enthusiastic amateurs who furnished an abundance of material and observations, as by the numerous large libraries, public museums and private collections to which they had access. Numerous entomological societies also brought the workers together, gave stimulus and encouragement and offered ready means of publishing.

How different the circumstances in America at that time! In the whole country there were no more persons scientifically interested in entomology than could be found in a single large city of Europe. The larger libraries were scant of entomological literature and there were neither standard nor public collections and but few private collections, of limited size. The most important of the older collections, viz., that made by Thomas Say, had been irretrievably lost through carelessness and indifference, while other valuable collections had shared no better fate. Contributions to the knowledge of our coleopterous fauna consisted chiefly of disconnected descriptions of single species scattered through all sorts of publications. "Can it be wondered at," LeConte wrote in one of his earliest papers, "that there is so much confusion 
about the synonymy of our species, when they are published in every country of the globe, but in that in which they ought to be published?" The thankless task of identifying and correctly interpreting these descriptions, involving so much labor and patient study, was performed almost alone by LeConte, and so well that but few species of the older authors remain to-day unidentified. LeConte clearly saw from the beginning that American coleopterology could not be so much advanced by mere descriptions of new species and genera as by conscientious monographic work. The number of such monographic and synoptic papers published by him was great. Of special importance among his earliest papers are those on the pselaphidae; on the classification of the longicorn coleoptera, and of the carabidae; on the elateridae and on the melolonthidae. In I86I his "Classification of the coleoptera of North America," prepared for the Smithsonian institution, began to appear. This work, though left incomplete until recently, was indispensible to every student of systematic coleopterology, and necessitated the publication of the "New species of North American coleoptera" and the "List of the coleoptera of North America," both issued by the Smithsonian institution.

His entomological writing was interrupted during the civil war, but was resumed again in $\mathrm{r} 865$. From this time on he had the coöperation of Dr. George Henry Horn, who, from the beginning of his entomological career, was a faithful co-laborer with LeConte. Indeed the friendship and coöperation that always existed between these two specialists is one of the most pleasing and instructive incidents in the history of American entomology. LeConte must have felt proud of the excellent work done by the younger naturalist, and the manner in which Horn's more advanced views and often more thorough labors - made possible by accumulated knowledge and material-were accepted, even where they undid much of his previous descriptive work, was one of the truest marks of greatness in LeConte. The most important papers of this later period are those on the classification of the rhynchophorous coleoptera, and more especially "The rhynchophora of America north of Mexico," by John L. LeConte, assisted by George H. Horn, published in 1876 as vol. I 5 of the Proceedings of the American philosophical society: a work which involved years of patient research and the value of which has not yet been fully recognized abroad. The last important work is the second and completed "Classification of the coleoptera of North America," by LeConte and Horn.

The list of Dr. LeConte's entomological writings has been carefully compiled (up to 1878 ) by Mr. George Dimmock, in his Special biblography, no. I, and the actual amount of his descriptive work is well illustrated in Mr. Samuel Henshaw's "Index to the coleoptera described by J. L. LeConte, M. D."' An additional paper by LeConte, to be published in the Transactions of the American entomological society, was about to be published at the time of his 
death, so that he may virtually be said to have died in harness.

This brief reference to his published papers reflects but feebly the character and value of LeConte's life and work. Throughout his writings there is the evidence of a calm, dispassionate, wellbalanced and philosophic mind, which, added to their accuracy, made him from an early day the leading authority on North American beetles the world over. Beginning when the idea of fixity of specific type was general, he easily followed the advance of evolutionary ideas, conforming his later work thereto, acquiescing and assisting in the "sinking" of his early species founded on too trifling variations.

His non-entomological writings evince culture, breadth of view and that rarest of qualities in specialists, common sense. He was not of the class who decry the practical application of knowledge as ignoble, but he felt rather that such application to man's wants is one of the aims of science. Thus he was always interested in the economic bearings of his favorite study and made several most valuable suggestions in his "Hints for the promotion of economic entomology in the United States" and his "Methods of subduing insects injurious to agriculture."

He was likewise for some years actively interested in endeavors to elevate the United States Department of agriculture, and was a candidate for the office of commissioner in 1877 . As president of the American association for the advancement of science in 1874 , and the first president of the Entomolo- gical club of that association, he took an active part in the attempt to bring about uniformity of terminology and the adoption of some general rules of nomenclature. He prepared, in conjunction with the writer, a memorial which in I875 was signed by many members of the association praying Congress for the creation of a special entomological commission on a plan that would have been in many respects preferable to that upon which the United States entomological commission was finally created in $\mathrm{I} 877$.

LeConte's taste for natural science was evidently inherited, and the family name is honored by several eminent scientists still living in this country and all of them, we believe, not very remotely connected. His father was a distinguished naturalist, and we were astonished at the beauty and accuracy of many of his yet unpublished drawings and paintings of animals which the son once showed us.

Few contemporary naturalists were better or more favorably known abroad than Dr. LeConte, and he was the first American elected to honorary membership of the Entomological society of France.

At a time when there was no national museum, before Dr. Horn had earned the fame he so richly deserves, and when the Amesican entomological society showed no promise of being able to appreciate or properly care for his valuable collection Dr. LeConte bequeathed it to the Museum of comparative zoology, at Cambridge, where in Dr. Hagen's care it will form the most 
precious systematic part of the Entomological department. When will our National museum fully warrant its name by becoming the one legitimate and most satisfactory repository of all such collections in whatever branch of science?

In closing this brief notice of one whose personal relations and whose appreciative and instructive correspondence with the writer during the past fifteen years will ever remain a green and pleasant memory, we would emphasize the fact that his writings throughout breathe a calm and judicial spirit, void of personality. The only instance that occurs to us where he gave expression to ruffled feeling is in the "Synopsis of the coleopterous insects of the group cleridae which inhabit the United States" (Annals lyceum nat. hist. N.Y., April I 849, v. 5, p 9-35). In the prelude to this paper he indulges in some severe reflections on the exclusive attitude of the Latin or South European countries toward the scientists of other countries. more particularly as exemplified by Spinola's work - reflections not altogether unwarranted even at the present time.

\section{GILLS OF INSECT-LARVAE.}

\section{By GeORge MACloskie, PRINCEton, N. J.}

The gills of aquatic larvae of insects consist of elastic sacs arising as outgrowths of the epidermis and enclosing a system of fine branches from the airtubes or tracheae, being thus pneumatic branchiae. They vary greatly in the number of the sacs, in the number and complexity of the enclosed air-tubes, and in their position. In the elmidae (of coleoptera) they are simple and are distributed ventrally on the abdomen ; in Ephemera (of neuroptera) they are also simple, and extend from the sides of the abdomen; sometimes they are caudal appendages, and in the libellulidae, or dragon-flies, they become complex, having in some cases many sac-like lamellae, and many hundreds of branches in each, the whole structure planted within the rectum, from the walls of which the lamellar sacs open like so many pockets.
These structures have been described by Réaumur, Léon Dufour, Audouin, Oustalet, ${ }^{1}$ and many others. Our present purpose is to rectify an error in their anatomy, as usually represented, which has important bearings on other questions.

It is usual to describe the laminae of the pneumatic gills as containing systems of fine tracheal loops, somewhat after the pattern of a plurality of carbonwicks in an Edison lamp. Oustalet says, for example, in the Annales des sciences naturelles (1869, s. 5, v. I I), that the branchial laminae "include a veritable chevelu of tracheae folded on themselves so as never to reach the extremity of the fingers of the glove;" and that they serve as a loose sheath

1 Ann. des sci. nat., Zool., 1852, s. 3 , v. 17 ; 1862, s. 4 , v. $17 ; 1869$, s. 5 , v. $11 ; 1872$, s. 5 , v. 16 . 

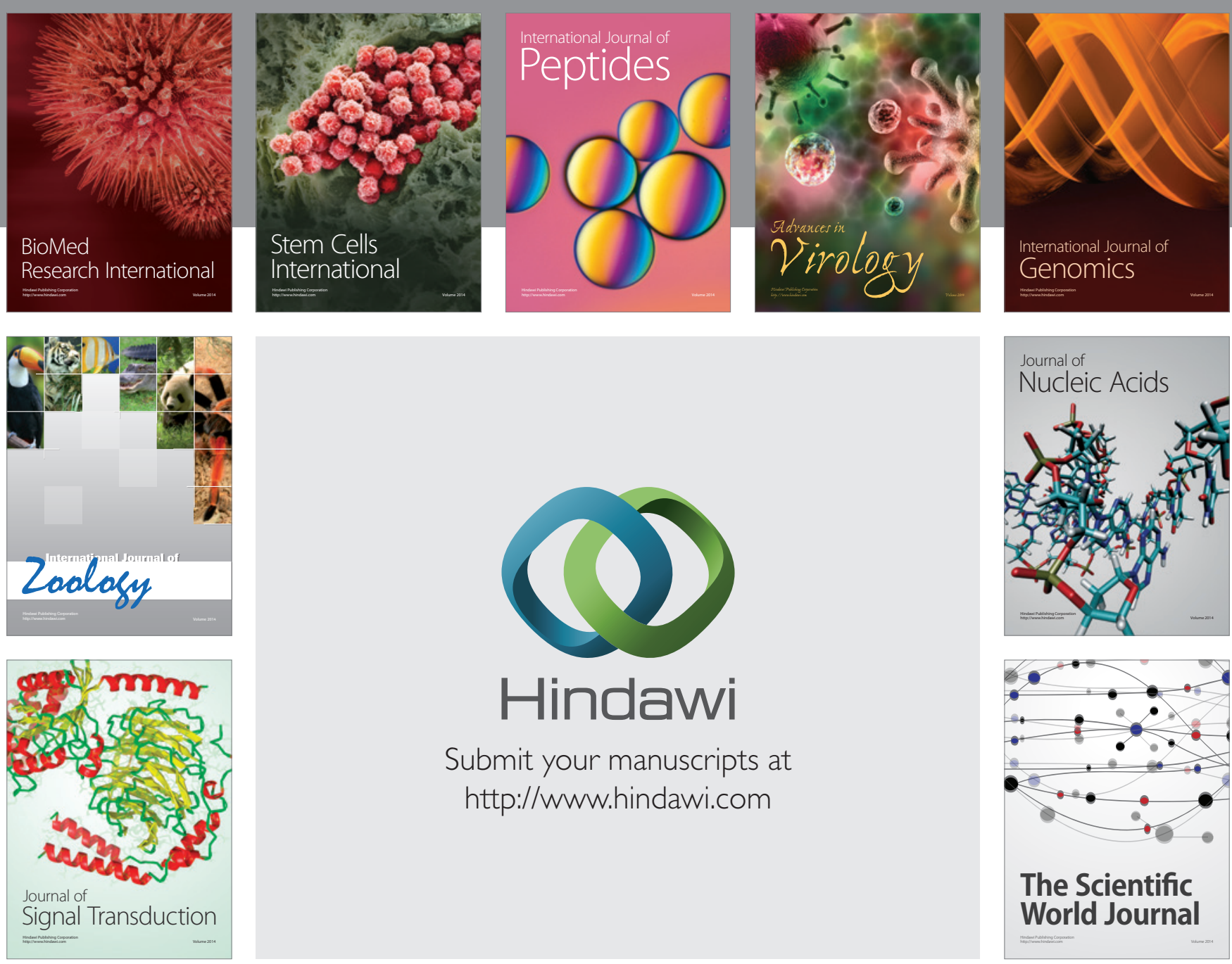

Submit your manuscripts at

http://www.hindawi.com
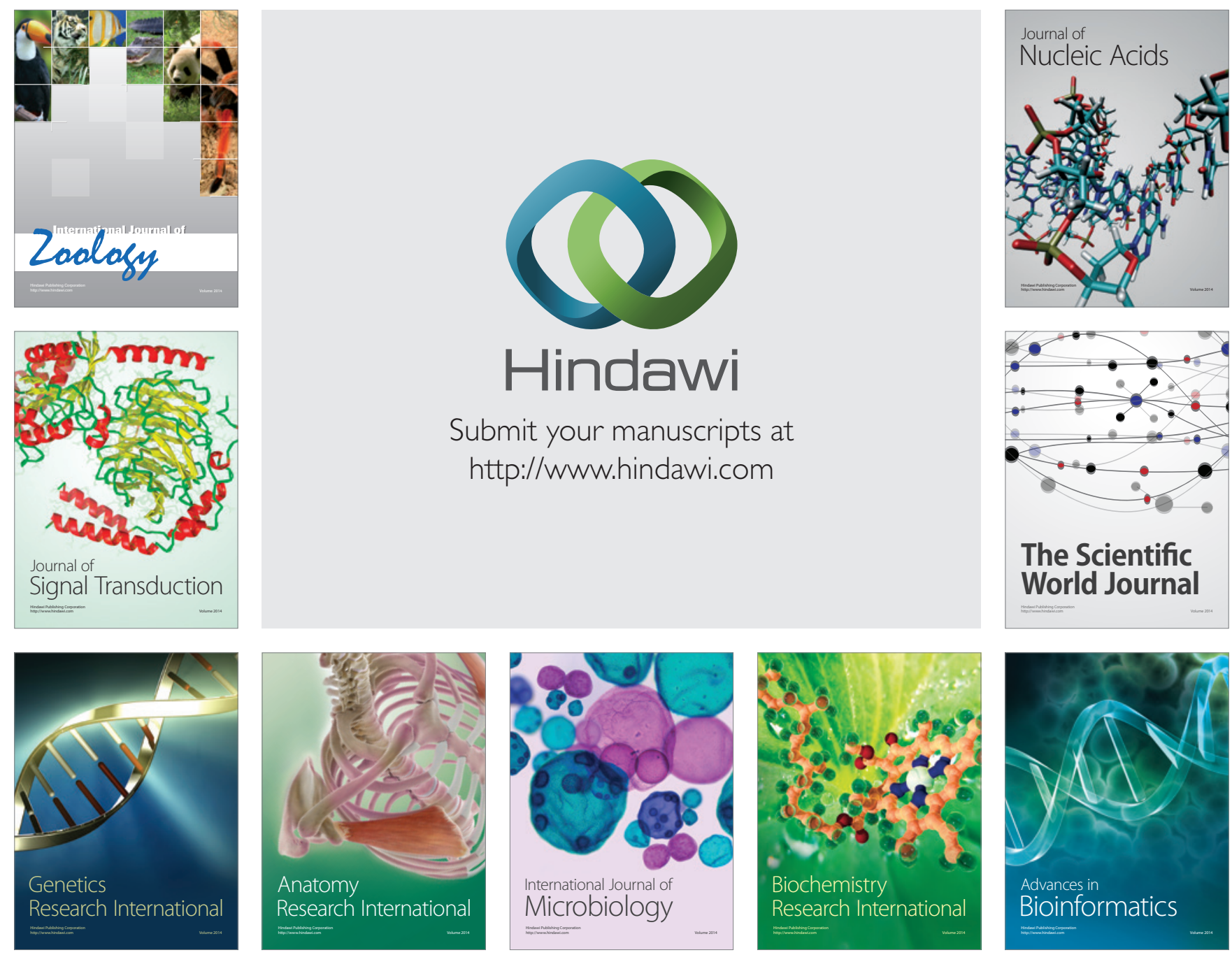

The Scientific World Journal
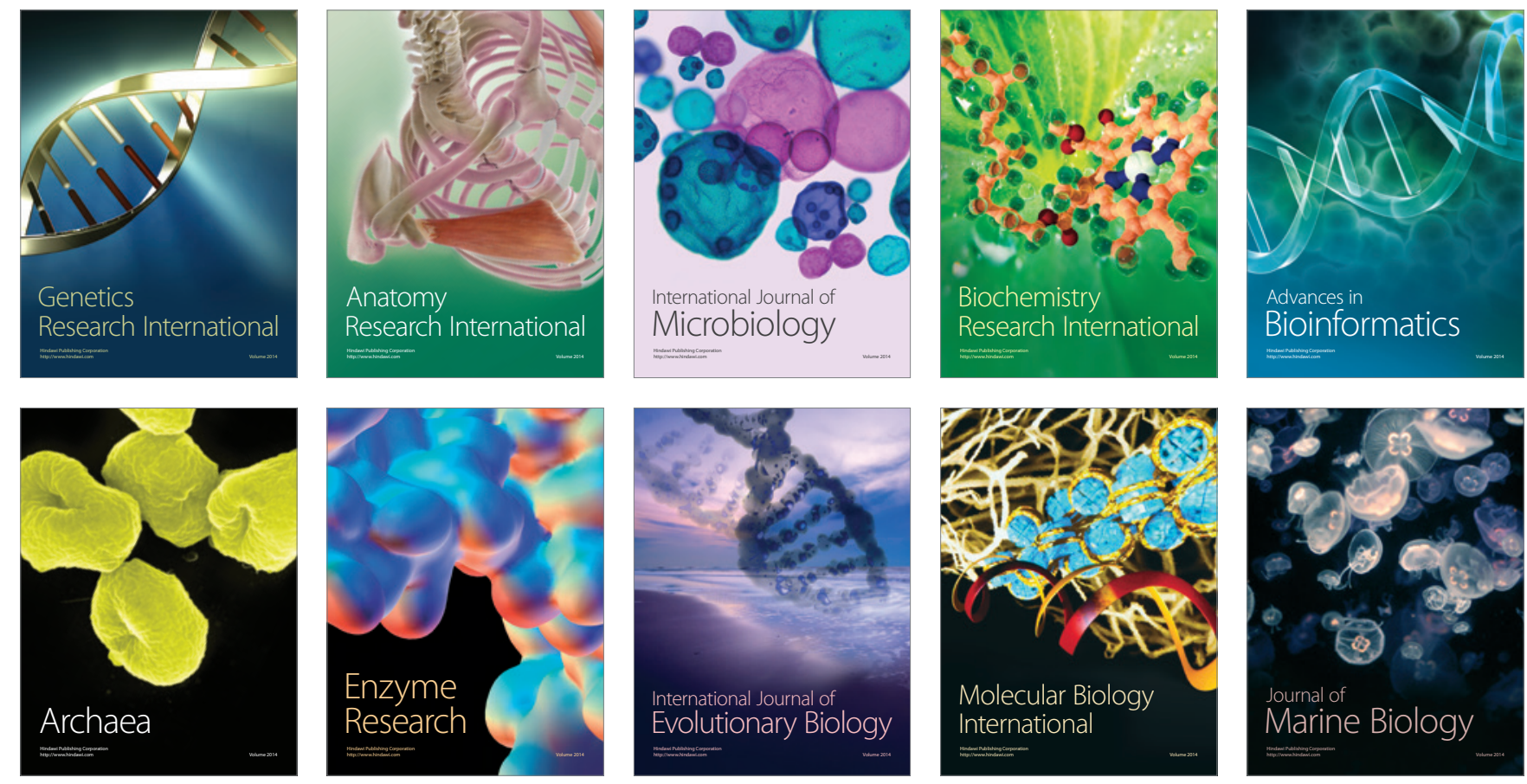